\title{
CARRYING CAPACITY ANALYSIS OF THE ENVIRONMENT AT COASTAL THE DISTRICT BANYUPUTIH SITUBONDO TO THE DEVELOPMENT CULTIVATION OF COTTONII SEAWEED (EUCHEUMA COTTONII)
}

\author{
Wafi Abdul ${ }^{1,2}$, Sambah Abu Bakar ${ }^{3}$, Adam M. Awaludin ${ }^{2 \star}$, Mahmudi Mohammad ${ }^{3}$ \\ ${ }^{1}$ Master's Program, Faculty of Fisheries and Marine Sciences, University of Brawijaya, \\ Indonesia \\ ${ }^{2}$ Faculty of Sciences and Technology, University of Ibrahimy, Indonesia \\ ${ }^{3}$ Faculty of Fisheries and Marine Sciences, University of Brawijaya, Indonesia
}

*E-mail: ar.adam87@yahoo.com

\begin{abstract}
Deterioration in the quality of seaweed cultivation in coastal Situbondo District of Banyuputih caused by several factors. One of these factors, such as suitability and environmental quality of coastal waters, become a major factor in cultivation. The study of aim to determine the relationship between environmental carrying capacity and the development of Eucheuma cottonii seaweed. The research method was carried out with the main supporting data collection, parameter growth analysis, spatial analysis using Geographic Information Systems (GIS), analysis of environmental carrying capacity, and strategies for developing seaweed cultivation. Evaluation of the parameters of the waters in the Banyuputih Subdistrict region can categorize as fulfilling the requirements for the development of seaweed cultivation using the floating raft method. The results of the analysis of land suitability for the development of seaweed cultivation divided into several categories, including very appropriate: 340.80 ha, as appropriate: 440.35 ha and incompatible: 720.97 ha. Effective land area for the development of seaweed cultivation $230.48(60 \%$ of the area is very suitable) with the number of rafts that can operate is 50,223 units. The strategy for developing seaweed cultivation in Banyuputih sub-district that needs to be applied is to refer to the management of the ecological-based aquatic environment, technological aspects in seaweed cultivation and regional arrangement by the carrying capacity of the environment.
\end{abstract}

\section{KEY WORDS}

Banyuputih, carrying capacity, E. cottonii, seaweed.

Nationally, the development of seaweed has declared by the Government in the 2006 2009 aquaculture revitalization program as the main commodity. Type of seaweed that has developed is Eucheuma sp and Gelidium sp (Adam, Maftuch, \& Hardoko, 2013). The seaweed cultivation business in East Java Province is currently not yet rapidly developing. Low community interest, lack of skills, limited marketing, underdeveloped manufacturing industry, and limited access to capital sources are the cause (Sulistiawati \& Rosyida, 2011).

The development of seaweed in Situbondo Regency has considerable prospects. World market demand in 2009 and 2010 is estimated to reach 98.9 - 109 thousand tons while the domestic market requires annually supply of 1,600 tons - 2,880 tons (Adam, Maftuch, Kilawati, Tahirah, \& Risjani, 2018) The high market demand for seaweed is closely related to its increasingly widespread use, not only for food and medicine, but for biodiesel and paper raw materials (Asmi, Subekti, \& Alamsjah, 2013).

The development of the potential of aquaculture in coastal waters in the Situbondo Regency is optimally directed to improve the welfare of the local community (Jumaidin, Sapuan, Jawaid, Ishak, \& Sahari, 2017) The activity still pays attention to aspects of resource conservation effectively, efficiently, optimally and sustainably. Related to this conceptual seaweed farming activities must be developed based on elements including the environment, technology, infrastructure, social culture, and community resources. District of Banyuputih coastal areas has the potential of aquatic resources for the development of 
seaweed farming. Seaweed is one of the marine resources that have benefits for the food industry, pharmaceuticals, and others. Seaweed contains agar, carrageenan, and alginate. Besides there are also carbohydrate content, protein, and a little fat which is a compound of sodium and potassium salts (Mahardika, Junaidi, \& Marzuki, 2018). Utilization of coastal and marine biological resources such as seaweed has long been carried out by coastal communities in Banyuputih District. During this time the coastal communities utilize seaweed still relying on natural products, and very few cultivate it. The type of seaweed cultivated and utilized in this region is the type of Eucheuma sp.

The decline in seaweed production is caused by ice-ice disease as a result of the presence of residential, agricultural, factory waste, and shipping waste. Waste affects the ecological conditions and the quality of the aquatic environment. Can inhibit the growth of seaweed, which results in decreased quantity and quality of seaweed.

In the development of seaweed cultivation in the District of Banyuputih, one of the main conditions that are very important is the suitability of the cultivation location. To determine the appropriate location, the use of satellite data and Geographic Information Systems (GIS) is one alternative to obtain accurate information and data (Asmi et al., 2013). The information obtained can be used as material for planning, supporting implementation, and for evaluating seaweed farming activities. The study conducted aim to determine the relationship between environmental carrying capacity and the development of Eucheuma cottonii seaweed.

\section{MATERIALS AND METHODS OF RESEARCH}

The materials used are label paper, tissue, questionnaire, seaweed type Eucheuma cottonii obtained from coastal waters of Banyuputih District. While the tools used are, rafts, nylon rope (PE), raffia ropes, anchors, scales, boats, scale sticks, pipes, GPS, refractometers, cool boxes, Nikon The 302 Series Theodolite, DO meters, sample bottles, plastic buckets, plastic bags, and stationery.

The study was conducted in the coastal area of Banyuputih Subdistrict, Situbondo Regency in January to April 2019. The research method used was descriptive by describing the actual situation and examining the causes of the symptoms of decreased quality of seaweed cultivation in Banyuputih District. Besides, a study was conducted on the ecology of Eucheuma cottonii seaweed in the waters of the District of Banyuputih using survey and experimental methods. At the location of the Banyuputih District waters, 3 (three) stations (St) trials for the growth of seaweed St.A, St.B, and St.C. Determination of the station is done purposively (according to the purpose of the study) based on the criteria and heterogeneity of the cultivation site. For this reason, a pre-survey was conducted to determine the location of the station based on the heterogeneity of the physical parameters of the waters through indicators of the waves, the strength of the currents and different habitats (rocky, sand mixed with sand, sand). The scope of the assessment of the carrying capacity of the aquatic environment includes: (1) Collection of primary and secondary data on physics and chemistry, especially dissolved nitrogen (BOD, TSS, PO4-P, H2S and NH3); (2) Data analysis and interpretation; (3) Determination of the optimum carrying capacity of the environment, production capacity and land area.

The data used are primary and secondary data's. Primary data collected through sampling, observation, questionnaires, and direct interviews at the research location. Primary data include condition of seaweed farming activities and parameters of coastal waters. While secondary data obtained through literature studies from various data sources such as the Regional Environmental Quality Balance Sheet, Situbondo in Numbers, Marine and Fisheries Service Reports, Regional Spatial Planning and administrative maps of Situbondo Regency, East Java Province.

The choice of location for the development of seaweed cultivation is essential for the proper cultivation locations must comply with the ecological conditions in marine waters, where the seaweed growth is largely determined by the ecology of the waters. Determining the suitability of a cultivation location is one of the ecological conditions carried out by looking at the biophysical and chemical conditions of the location of seaweed cultivation by 
comparing the results with the quality standards or requirements for growing seaweed cultivated in the Mlandingan area of Situbondo.

The biophysical parameters of the environment in each location tend to be varied;therefore, to see these variations in achieving the research objectives, it is necessary to group data analysis based on the research objectives.

Analysis of the daily growth rate of cultivated seaweed is calculated based on the following formula (Ulnang, L, \& Momo, 2018):

$$
G=\left[\frac{W t}{W o}\right]^{1 / t} 1 \times 100 \%
$$

Where: $\mathrm{G}=$ Seaweed growth rate (\%); $\mathrm{Wt}=$ The weight of the wet/dry seaweed at $\mathrm{t}$ days (average final) (gr); Wo = The weight of the wet/dry seaweed on the initial investment (average start)(gr); $t=$ Planting time $/$ testing time.

Determination of carrageenan content can be measured by the following formula (Sulistiawati \& Rosyida, 2011):

$$
\text { Carrageenan }(\%)=\frac{\text { WeightCarrageenan }}{\text { WeightTestSample }} \times 100 \%
$$

Determine the suitability of land in an area of water in the development of optimal and sustainable seaweed cultivation that guarantees coastal sustainability, the spatial analysis method is used in spatial analysis. There are several steps that must be done, namely the compilation of spatial databases and overlay techniques.

Preparation of spatial database is intended to make a digital thematic map that starts with basic maps, data collection (compilation of data) up to the stage of overlaying. In this study, the types of data taken include ecological waters such as temperature, salinity, waves, tides, currents, brightness, and water substrate. Based on these data, contours will be made on each criterion with the help of Extention Gird Contur so that the contours of the contours are formed in cover to polygon which produces the theme itself. The results of this polygon or coverage (layer) are used for the overlay process(Boruff, Moheimani, \& Borowitzka, 2015).

To determine the mapping of an area that is suitable and not suitable for the development of seaweed cultivation in the study area, overlay operations of each theme used as the criteria, using Arc View 3.2. Before this stacking overlay operation was carried out, each theme was assessed as having a degree of influence on determining land suitability. Giving values to each of these themes uses weighting. Each theme is divided into several classes (which are adapted to the conditions of the study area) given scores ranging from influential classes to classes that do not affect. Each class will get the final score, which is the result of multiplication between the class scores and the weight of the theme where the class is located. Determination of criteria, assigning weights, and scores are determined based on literature studies and justifications that are competent in the field of fisheries (Jelokhani-Niaraki, Sadeghi-Niaraki, \& Choi, 2018).

The process of giving weights and scores as above is done through the model overlay index approach to obtain the land suitability class sequence. This model requires that each coverage be given a weight, and each class in one coverage is given a value (Pena, Magalhães, \& Abreu, 2018). The results of multiplication between weights and scores received by each coverage are adjusted based on the level of importance of determining the suitability of seaweed cultivation land.

In determining the utilization of coastal areas as seaweed cultivation land, a cultivation system is needed that takes into account the carrying capacity of the aquatic environment where cultivation activities take place in determining the business scale or size of business units that can guarantee continuity of seaweed cultivation activities.

The estimation of the carrying capacity of the aquatic environment will show how many units of raft can be planted in the specified area. To analyze the carrying capacity of the environment using an approach from formulation proposed by (Aqmal, Tuwo, \& Haryati, 
2016) were to estimate the carrying capacity of the environment is to compare the area of an area used with the unit area of seaweed cultivation methods. With the formula as follows:

$$
\text { Carrayingcapacity }=\text { ax } \frac{L K L}{L U M}
$$

Where: LKL - Capacity comprehensive land suitability; LUM - The area of the unit method; $\alpha$ - Effective cultivation coefficient (60\%).

\section{RESULTS AND DISCUSSION}

Aquaculture activities potential negative impact on the environment due to the waste load. These impacts such as nutrient enrichment, eutrophication, hypoxia and sedimentation. Therefore, aquaculture must be conducted in accordance with the carrying capacity of the environment. Here in Table 1 show the data carrying capacity of the environment studied ecologically.

Table 1 - Ecological Carrying Capacity of Seaweed Cultivation

\begin{tabular}{cccc}
\hline Parameters & \multicolumn{3}{c}{ Stations } \\
\cline { 2 - 4 } & St A & St B & St C \\
\hline Temperatur $\left({ }^{0} \mathrm{C}\right)$ & $28,0 \pm 0,7$ & $27,5 \pm 0,3$ & $27,4 \pm 1,4$ \\
Salinity (\%o) & $30,0 \pm 0,8$ & $30,1 \pm 0,6$ & $29,0 \pm 0,7$ \\
Brightness (m) & $2,6 \pm 0,4$ & $6,6 \pm 0,2$ & $3,6 \pm 0,3$ \\
Deepness (m) & $3,6 \pm 0,2$ & $10,9 \pm 0,2$ & $4,6 \pm 0,2$ \\
DO (mg/l) & $5,4 \pm 0,2$ & $5,9 \pm 0,4$ & $6,0 \pm 0,3$ \\
Flow (cm/det) & $17,3 \pm 1,0$ & $17,2 \pm 1,1$ & $18,2 \pm 1,2$ \\
Nitrat (mg/l) & $3,1 \pm 1,2$ & $3,2 \pm 1,4$ & $2,7 \pm 0,9$ \\
Fosfat (mg/l) & $0,9 \pm 0,6$ & $1,3 \pm 1,1$ & $1,6 \pm 0,5$ \\
\hline
\end{tabular}

Based on the data shown in Table 1 that the ecological carrying capacity for seaweed cultivation in the study location is in accordance with the quality standard. The ecological determination of the carrying capacity of the environment takes into account the status of utilization, spatial analysis can calculate the maximum area and capacity of the number of rafts. Consideration of the shipping lane area as well as reducing the port area as well as shrimp farming area are other factors. This factor is to avoid conflicts of interest between water users.

According to (Asyiawati, n.d.) that ecological carrying capacity is the maximum number of individuals on land that can be supported without causing death due to density factors, and the occurrence of permanent environmental damage.

Estimation of the carrying capacity of the water Estimation of the carrying capacity of the aquatic environment in Banyuputih District for the development of seaweed cultivation is carried out with 3 approaches, namely the area of seaweed cultivation, the maximum number of rafts and the total seaweed production. Information needs related to the spatial distribution of cultivation development locations are equipped with production capacity data from the cultivation unit. In addition, the maximum data on the number of rafts and cultivation practices is in accordance with operational standards and the minimum distance agreement between cultivation units.

The measurement results the growth rate of seaweed cultivated in three (3) stations to variations. Wet weight of seaweed when observations showed an increase from day 10 to day 60 (Figure 1). Weight seaweed showed an increase from day 10 to day 60 at station $A$ and $B$, it is suspected that environmental factors because they support. Among them is enough nutrients and also a relatively good flow velocity. Their mixing process caused the absorption of nutrients by the seaweed indicated either. In contrast to station C, showed growth of seaweed relative decline. This is presumably because the flow is not good, resulting in absorption of nutrients becomes abnormal. 


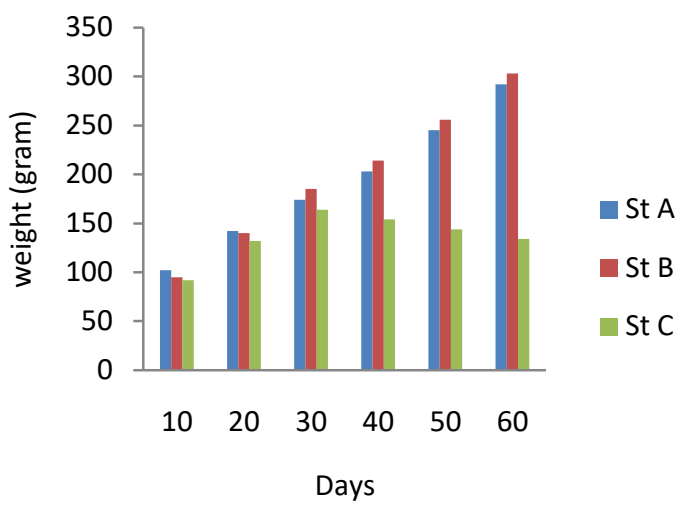

Figure 1 - Seaweed Wet Weight

Besides other factors such as sunlight, temperature, salinity, waves, oxygen also influences the growth and development of seaweed (Sujarwo \& Fitriyanny, 2016). The seaweed growth rate at stations $A$ and $B$ is higher than that of station $C$. This is thought to be due to environmental conditions other than fluctuating velocity, temperature, salinity, waves, oxygen and turbidity that inhibits growth. Whereas at station $\mathrm{C}$ with a rocky substrate condition but there is disturbing biota that eats seaweed and thus inhibits growth.

The results of measurements are carrageenan seaweed (Eucheuma cottonii) on day 10 to day 60 is shown in Table 1.

Table 1 - Results of Measurement of Carrageenan Level Seaweed Eucheumacottonii

\begin{tabular}{cccc}
\hline \multirow{2}{*}{ Days } & \multicolumn{3}{c}{ Carrageenan content (\%) } \\
\cline { 2 - 4 } & St A & St B & St C \\
\hline 10 & 17,03 & 19,12 & 22,88 \\
20 & 22,01 & 21,78 & 24,61 \\
30 & 24,11 & 20,19 & 36,98 \\
40 & 32,11 & 33,24 & 38,76 \\
50 & 42,43 & 40,67 & 24,21 \\
60 & 22,32 & 24,90 & \\
\hline
\end{tabular}

Carrageenan is obtained from the extraction of The use of seaweed in the industry based on the content of koloidnya ie agar, carrageenan and alginates. Carrageenan obtained from an extract of red algae (Rhodophycae) which has three types, namely kappa carrageenan, iota, and lambda. The type of carrageenan produced by Eucheuma cottonii is carrageenan kappa. Carrageenan content of seaweed varies for each species and also for different water locations. (Rahman, 2016).

The results of measurements of carrageenan content at each station varied based on the observation day, with the maximum carrageenan content on day 50 .

Based on the graph above it can be seen that there is an increase in carrageenan from day 10 to day 50 , and there is a decrease on day 60 for all stations (stations $A, B$ and $C$ ). The levels of carrageenan seaweed planted in stages $A, B$ and $C$ give different carrageenan values. The highest levels of carrageenan with a value of $41.55 \%$ at $33.89 \%$ moisture content dry weight found at station B. While the content of carrageenan at stations $\mathrm{A}$ and $\mathrm{C}$ are 40.45 with water content of $32.83 \%$ and 39.00 with a moisture content of 34.50 . The increase in the content of carrageenan is suspected due to the environmental conditions of the waters such as temperature, salinity, brightness, good current movement and the availability of nutrients that support the growth of seaweed. In addition, the growth of seaweed that is old enough to produce high levels of carrageenan. The content of carrageenan at station $B$ is higher than that of stations $A$ and $C$. This is presumably due to the condition of the sandy-grained substrate so that no turbidity and good brightness can accelerate the photosynthesis process in seaweed.

At station A the substrate conditions are muddy and also the station is close to shrimp 
farming activities so that stirring will occur resulting in turbidity, which will inhibit the photosynthesis process and the nutrient diffusion process decreases. Whereas in station five the condition of the rocky substrate so that turbidity is not easy to occur and a good level of brightness can accelerate the photosynthesis process, but many disturbing bacteria eat thallus so that it can disrupt growth.

On the 60th days, there was a decrease in carrageenan levels at all stations. This is because on the 60th day this is thought to be influenced by the origin of thallus and the type of seed used for cultivation where the type of seedlings that are by the environment will produce high carrageenan content. Also, itis suspected that cellulose formed by part of carrageenan will turn into a reserve of energy needed to maintain its presence in the water.

The best levels of seaweed carrageenan on the 50th day when compared to the wet weight of seaweed which peaked on the 60th day was due to the sufficient age to produce carrageenan levels on the 50th day, despite the growth of seaweed (somatic growth) still growing but the physiological age (colloidal content) of seaweed is enough to be harvested.

According to (Syarqawi, Afdhal, Rahimi, \& Rusydi, 2017) that in addition to environmental factors, internal factors also play a role in the formation of carrageenan content, including age factors. The growth of the thallus and the number of branches that are old enough to produce high levels of carrageenan. According to (Kadi, 2004)that the age of plants is very influential on the content of carrageenan levels and other compositions.

The highest carrageenan content in this study was $40.00-41.55 \%$. Several studies of carrageenan levels carried out in Indonesia show mixed results at locations for different locations. The results of research on the content of seaweed carrageenan in the waters of BanyuputihSubdistrict are relatively good but lower than the research of $48 \%$ in Lhokseudu Aceh, 68.35\% in Bluto and 52.11 in Tamiang Bay.

According to (Widowati, Rejeki, Yuniarti, \& Ariyati, 2015), about CAY (standard carrageenan levels) for seaweed by $40 \%$. Furthermore, according to (Soenardjo, 2011) that carrageenan levels are strongly influenced by local conditions, where the life cycle of algae also plays a role in determining the quality of carrageenan. (Muhamad Fikri, Sri Rejeki*), 2015)states that the carrageenan content of seaweed varies greatly depending on species, stages of growth,and local environmental conditions.

Marine waters in Banyuputih Sub-district that have natural resource potential for the development of marine aquaculture, one of which is seaweed cultivation. Support these activities; it is necessary to analyze land suitability/location wherein determining the location of seaweed cultivation; several requirements need to be considered as indicators that support these activities (Adam, Maftuch, Kilawati, \& Risjani, 2019).

In this study, an ecological study was conducted as an indicator to determine the level of suitability of land for seaweed cultivation in the waters of BanyuputihSubdistrict by making a land suitability map.

Suitability analysis is conducted based on limiting factors/parameters according to their utilization in terms of ecological aspects(Syarqawi et al., 2017). The initial criteria are generally composed of ecological prerequisites, then the results of GIS analysis in the form of location and area that are by the required criteria which ultimately determine the carrying capacity of the land(Jelokhani-Niaraki et al., 2018; Syarqawi et al., 2017). This analysis is intended to assess the feasibility or suitability of the land area of Banyuputih Sub-district. The results of the analysis are grouped into three categories, which are Not Suitable (St $A$ ), Suitable (St B), and very suitable (St C).

Based on spatial analysis with the Geographic Information System (GIS) approach, a land suitability class for seaweed cultivation will be obtained through several stages.Including 1) determining the value of each parameter by making a matrix containing scores and weights. 2) data for each parameter is entered or digitized on the map so that they will be obtained thematic maps. 3) by overlaying all thematic maps, namely thematic temperature, salinity, depth, brightness, DO, nitrate, phosphate, substrate, then the total value of each parameter is obtained. 4) the total value will be adjusted according to the suitability class range which is class 1 (not suitable) in the range 275-355, class 2 (accordingly) ranges from 356-435 and class 3 (very suitable) ranges from 436-515. 


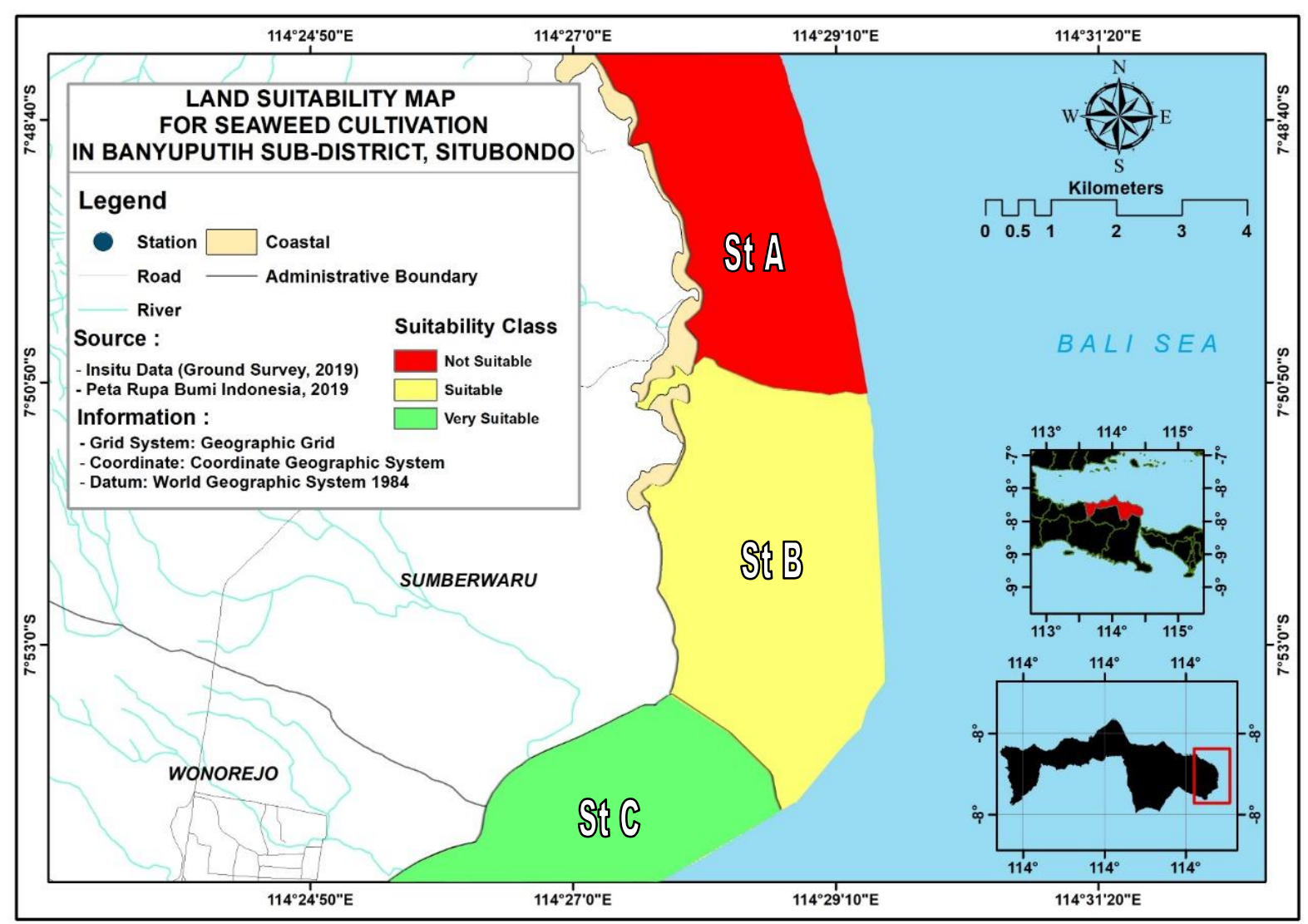

Figure 2 - Seaweed Growth Suitability Map (Eucheumacottonii) in Banyuputih District in 2019

The results of land suitability evaluation/analysis show that the land area for the development of seaweed cultivation in terms of growth parameters (aquatic ecology) and carrageenan content produces three categories of land suitability which are very suitable is 340.80 ha, corresponding to 440.35 ha and not according to 720.97 ha. For more details, see the land suitability overlay map in Figure 2.

\section{CONCLUSION}

Evaluation of the ecological parameters in the research waters of the BanyuputihSubdistrict can be categorized as fulfilling the requirements for the development of seaweed cultivation using the floating raft method. The strategy for developing seaweed cultivation in Banyuputih sub-district that needs to be applied is to refer to the management of the ecological-based aquatic environment, technological aspects in seaweed cultivation and regional arrangement by the carrying capacity of the environment.

\section{REFERENCES}

1. Adam, M. A., Maftuch, M., \& Hardoko, H. (2013). Aktivitas Antibakteri Ekstrak Fenol Gracillaria verrucosa terhadap Bakteri Aeromonas salmonicida secara in vitro. Natural B, 2(1), 1-2. https://doi.org/10.21776/ub.natural-b.2013.002.01.2.

2. Adam, M. A., Maftuch, M., Kilawati, Y., \& Risjani, Y. (2019). Clinical Symptoms of Gambusia Fsih (Gambusia affinis) After Exposure to Cadmium Absorbed in The Gills. Pollution Research, 38(March Suppl. Issue), 88-93.

3. Adam, M. A., Maftuch, M., Kilawati, Y., Tahirah, S. N., \& Risjani, Y. (2018). Analysis of Heavy Metal Pollutant in Wangi River Pasuruan and Its Impact on Gambusia affinis. Jurnal Pembangunan Dan Alam Lestari, 9(2), 120-128. https://doi.org/10.21776/ub.jpal.2018.009.02.09. 
4. Aqmal, A., Tuwo, A., \& Haryati, H. (2016). Analisis hubungan antara keberadaan alga filamen kompetitor terhadap pertumbuhan dan kandungan karaginan rumput laut Kappaphycus sp. di Provinsi Sulawesi Selatan. Jurnal Rumput Laut Indonesia, 1(2), 94102.

Retrieved

from https://journal.indoseaweedconsortium.or.id/index.php/jrli/article/view/25.

5. Asmi, L. W., Subekti, S., \& Alamsjah, A. (2013). Desa Grujugan Kecamatan Gapura Kabupaten Sumenep Correlation Of Growth And Carragenan Content Of Kappaphycus Alvarezii And Eucheuma Spinosum By Different Distance Placement Of Floating Rafts, 5(2), 217-222.

6. Asyiawati, Y. (n.d.). Pengaruh Pemanfaatan Lahan Terhadap, 10(2), 1-5.

7. Boruff, B. J., Moheimani, N. R., \& Borowitzka, M. A. (2015). Identifying locations for largescale microalgae cultivation in Western Australia: A GIS approach. Applied Energy, 149, 379-391. https://doi.org/10.1016/j.apenergy.2015.03.089.

8. Jelokhani-Niaraki, M., Sadeghi-Niaraki, A., \& Choi, S. M. (2018). Semantic interoperability of GIS and MCDA tools for environmental assessment and decision making. Environmental Modelling and Software, 100, 104-122. https://doi.org/10.1016/j.envsoft.2017.11.011.

9. Jumaidin, R., Sapuan, S. M., Jawaid, M., Ishak, M. R., \& Sahari, J. (2017). Effect of seaweed on mechanical, thermal, and biodegradation properties of thermoplastic sugar palm starch/agar composites. International Journal of Biological Macromolecules, 99, 265-273. https://doi.org/10.1016/j.ijbiomac.2017.02.092.

10. Kadi, A. (2004). Potensi Rumput Laut Dibeberapa Perairan Pantai Indonesia. Oseana, XXIX(4), 25-36.

11. Mahardika, S., Junaidi, M., \& Marzuki, M. (2018). Kandungan Klorofil-A Dan Fikoeritrin Pada Rumput Longline Dengan Kedalaman, 1.

12. Muhamad Fikri, Sri Rejeki`), L. L. W. P. (2015). Produksi Dan Kualitas Rumput Laut (Eucheuma Cottonii) Dengan Kedalaman Berbeda Di Perairan Bulu Kabupaten. Jepara Production. Journal of Aquaculture Management and Technology, 4, 67-74.

13. Pena, S. B., Magalhães, M. R., \& Abreu, M. M. (2018). Mapping headwater systems using a HS-GIS model. An application to landscape structure and land use planning in Portugal. Land Use Policy, 71(May 2016), 543-553. https://doi.org/10.1016/j.landusepol.2017.11.009.

14. Rahman, A. (2016). Pengaruh Jarak Antar Tali Gantung Vertikultur Terhadap Kestabilan Tali Bentang Vertikultur Rumput Laut (Kappaphycus alvarezii) Dengan Metode Bentuk Segi Tiga Terbalik Seri [ The Effect of Hangging Rope Distances on the Rope Stability of Seafood Culture, 1(1), 27-36.

15. Soenardjo, N. (2011). Aplikasi budidaya rumput laut Eucheuma cottonii (Weber van Bosse) dengan Metode Jaring Lepas Dasar (Net Bag) Model Cidaun. Buletin Oseanografi Marina, 1(1), 36-44. Retrieved from https://ejournal.undip.ac.id/index.php/buloma/article/view/2970.

16. Sujarwo, P. A., \& Fitriyanny, W. P. (2016). Pengelolaan Budidaya Rumput Laut Berkelanjutan Untuk Masyarakat Pesisir Pulau Panjang Serang, Banten. Jurnal Kebijakan Sosial Ekonomi Kelautan Dan Perikanan, 6(2), 123. https://doi.org/10.15578/jksekp.v6i2.3326.

17. Sulistiawati, D., \& Rosyida, E. (2011). Analisis kandungan karaginan dan kelayakan usaha agroindustri rumput laut di kabupaten morowali, 12(2), 126-132.

18. Syarqawi, M., Afdhal, S., Rahimi, E., \& Rusydi, I. (2017). Pengaruh Penggunaan Kantong Terhadap Pertumbuhan Rumput Laut (Eucheuma cottoni) di Perairan Kabupaten Simeulue The Influence of Seaweed Bag on The Growth of Seaweed (Eucheuma cottoni) in The Waters of Simeulue Regency, 2(April), 277-285.

19. Ulnang, J. A., L, R. M. T., \& Momo, A. N. (2018). Produktifitas Rumput Laut Eucheuma Spinosum Di, 15(3), 88-96.

20. Widowati, L., Rejeki, S., Yuniarti, T., \& Ariyati, R. (2015). Efisiensi Produksi Rumput Laut E. Cotonii Dengan Metode Budidaya Long Line Vertikal Sebagai Alternatif Pemanfaatan Kolom Air. Jurnal Saintek Perikanan, 11(1), 47-56-56. https://doi.org/10.14710/ijfst.11.1.p 